\title{
Ideal Family Interpretation In The Al-Qur'an
}

\author{
Hafidzoh Nisa ${ }^{1}$, Kusmana $^{2}$, Yudi Setiadi ${ }^{3}$, Diah Hasanah ${ }^{4}$, Amany Lubis ${ }^{5}$, Masri Mansoer ${ }^{6}$, \\ Usep Abdul Matin ${ }^{7}$ \\ \{hafidzohnisa13@mhs.uinjkt.ac.id ${ }^{1}$, kusmna@uinjkt.ac.id²,yudi.setiadi14@mhs.uinjkt.ac ${ }^{3}$, \\ diah.hasanah15@mhs.uinjkt.ac.id ${ }^{4}$, amany.lubis@uinjkt.ac.id ${ }^{5}$, masri.mansoer@uinjkt.ac.id ${ }^{6}$, \\ usep.abdulmatin@uinjkt.ac.id ${ }^{7}$ \} \\ Syarif Hidayatullah State Islamic University of Jakarta, Indonesia ${ }^{1234567}$
}

\begin{abstract}
The concept of family in the al-Qur'an is a command to be a happy family for each other. If this cannot be realized in a family then the family cannot be said to be a family that is by the concept of the Qur'an. As mentioned in the Quran ar-ruum commands to make a family a family that is happy with each other.
\end{abstract}

Keywords: Ideal Family, al-Qur'an, Interpretation.

\section{Introduction}

Marriage in Islam aims so that mankind can achieve ideal happiness and fulfill the elements of Sakinah ma waddah wa rahmah. Along with the development of the information age and the flow of globalization, it shows and demands attention that requires awareness, especially in Islamic families. Islam in interpreting Sakinah mawaddah wa rahmah in family life.

The author of this research focuses on discussing the concept of marriage in the Quraish Shihab to discuss the ideal family. The author would like to have a deeper look at the Quran surah ar-rum according to the Quraish Shihab as well as to compare research on classical and contemporary thought to find common ground for this wetting.

Marriage is an inner and spiritual bond between a man and a woman as husband and wife to form a happy and eternal family or household based on the divinity of the Almighty. Marriage is not only temporary but continues between husband and wife in a happy family or household.

In the elucidation of Article 1 of Law No.1 of 1974, it is said that the bond of inner birth is an important thing of marriage because the purpose of marriage is not merely to fulfill the lusts, but to create a happy family and based on the divinity of the Almighty.

Marriage aims to foster human life in harmony, peace, and happiness so that life can love one another and love between husband and wife and children and other families so that a prosperous family can be created. Harmony and harmony in the home are very much needed by children because it is the only place and natural environment that can be used to educate children properly, both physical education and spiritual education, and can foster love and affection in their souls.

Parents have a great responsibility for the development and education of children, healthy and clean households that are filled with a sense of peace of security and peace and harmony 
with one another will create a happy family that lives in society by giving birth to children who are educated and have bright hopes in the future. The harmonistic relationship between parent and child is very influential on the growth and development of the child's soul and education, a harmonious relationship full of understanding and affection will bring to the child's personality. Considering that the household is the first place of education known by children, parents must be able to know about the purpose of education for their children.

Al-Qur'an is a guide to the way of human life, especially followers of Islam because in it there is wisdom and guidance for anyone who wants to achieve the happiness of the afterlife. The Qur'an which has been proven beyond doubt is indeed worth mentioning the gift of the greatest and most real miracle, is it not called a miracle if it is not stated truthfully.

However, this is the Koran which is really about the problems of life, the principles of faith, the rule of law, the moral values of all summarized in the Koran and it deserves to be said as a miracle. In the Qur'an mentioned above that the Qur'an is used as a guide to life as a law book for Muslims, it has arranged so neatly in providing solutions, responses, signs of happiness to humans. Some small examples of the Qur'an have given the family concept of how to achieve happiness in the family.

This writer wants to know how the ideal family concept is core to achieving the gift of happiness with the concept that can be reached by tracing the verses of the Qur'an ar-Ruum: 21. at-Tahrim: 6, and al-Anfal: 28 , which the authors consider is the concept of a happy family.

Family institutions are small social units in society. If the family is good, then the community will be good too. Welfare in the community has a close relationship with the formation of individuals in quality family institutions according to Islam. This article will bring an understanding of the family according to Islam, the concept of the family according to Islam, and the characteristics of a quality family based on the propositions of the Koran and al-Sunnah. Understanding of family quality according to Islam is very important to Muslims to achieve the true marriage matrimony and to serve the challenges of life during their full period of faith and wisdom.

According to Harun Nasution, the verses regarding family have a large amount in the Qur'an. The number of family life is a lot in the Koran because the family is the smallest social unit in each society. A good, prosperous, and happy family is made up of a good and happy society. Families that are not strongly bonded will not be able to form a good society.

Therefore the firmness of family ties needs to be maintained and this is where one lies, so the verses about family are numerous in the Qur'an. In this connection, it is well to remember that the purpose of worship in Islam is to form good individuals who will be noble. Individuals who do not have a noble character will not be able to form a good family.

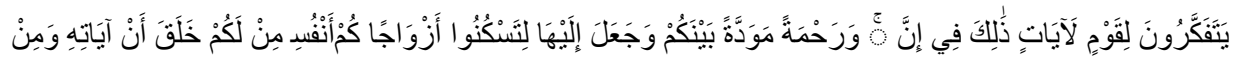

It means: "And among the signs of His power is He created for you wives of your kind so that you are inclined and feel at ease with him, and He made you with love and affection. Surely in that, there are signs for people who think. ". [Q.S Ar-Rūm: 21]

In the elucidation of Article 1 of Law No.1 of 1974, it is said that the bond of inner birth is an important thing of marriage because the purpose of marriage is not merely to fulfill the lusts, but to create a happy family and based on the divinity of the Almighty. Marriage aims to foster human life in harmony, peace, and happiness so that life can love one another and love between husband and wife and children and other families so that a prosperous family can be created. Harmony and harmony in the household is needed by children because it is the only 
place and natural environment that can be used to educate children properly, both physical education and spiritual education, and can foster love and affection in their souls

Parents have a great responsibility for the development and education of children, a healthy and clean household that is filled with a sense of peace of security and peace and harmony with one another will create a happy family that lives in society by giving birth to children who are educated and have bright hopes in the future. A harmonious relationship between parent and child is very influential on the growth and development of the soul and education of the child, a harmonious relationship full of understanding and affection will bring to the child's personality

One of the main problems that are often faced by husband and wife, is the economic needs in the household. The inability of a husband to meet economic needs will lead to disharmony between husband and wife who easily triggers divorce. So the data in the Ambon Religious Court shows that the biggest contributing factor to divorce is disharmony which is also closely related to economic problems.

In this connection, the divorce rate in the Ambon Religious Court was dominated by ethnic migrants from outside Maluku. While the divorce rate of the indigenous population is relatively low, due to the still strengthened kinship, family solidarity, and local wisdom. Also, the wife views divorce due to economic pressures, as an irresponsible husband, the quantity of divorced speech from the husband will hamper meeting daily needs; and a husband who is lazy to work is a dishonorable act

Of all the affairs of infidelity, the most important problem of infidelity is divorce, because infidelity is one of the problems of marriage breakup. Efforts to deal with infidelity include overseeing the relationship of husband or wife, trying as hard as possible to create a harmonious household atmosphere, trying to set a good example, build a conducive environment, improve the quality of values religious values, a solid foundation of love, realizing transparent and harmonic communication, increasing strength and resilience based on self-concept and confidence confidently, developing good and healthy social contact, associating with good people

Table 1. Data of Marriage breakup.

Early marriage often brings problems because the level of emotional control of young couples is not yet stable. In a marriage, various problems will be found that demand maturity in handling so that marriage is not seen as mere material readiness, but also mental readiness and maturity to navigate.

Economic needs are indeed a very important basic need for every aspect of the household. Less economic needs will lead to bad things, thus triggering problems between husband and wife. One of these problems is the occurrence of acts of domestic violence (KdRT), which can occur because of the background of the economic problems faced in the family.

Married life can be called unifying two uniqueness. The difference in character, character, taste, and knowledge of two people who are united in the household, living together for a long time. Some household problems that require counselors or counselors in solving their problems include; Inadequate economic problems can trigger tension in the family, differences in character and character as well as personality differences that are too sharp between husband and wife who find it difficult to find common ground, busy husband and wife who are more out of the house and infidelity. Likewise, the education gap between husband and wife, the boredom of routine especially wives who do not have activities outside the home and the main thing is because it is far from religion 
Complex problems caused by gender in a family, such as differences of opinion about the importance of education in the family, husband/wife career, child care, child delinquency, to domestic violence (domestic violence) ) experienced by the wife/women and children, all of this must be solved in a family manner with the help of counselors who understand gender with all the problems it causes

The impact experienced by the research subjects when the husband left working outside the area, namely on the physiological, economic, and child aspects which are stressors. The subject's effort to be able to cope with the stress that arises. Stress management used by both subjects is solving problems, drawing closer to God, working in a reasonable portion. Harmonization, sharing, recognizing the causes of stress, crying, good planning, and maintaining health

Marriage divorce trends in the community, this phenomenon is in the spotlight of researchers. As if the perpetrators of a divorce do not consider marriage to be a sacred contract. In this case, the effect of the divorce event affects the satisfaction of a legal marriage. The ideal family concepts in the Qur'an are mentioned as families that have the concepts of Sakīnah Mawaddah and Rahmah.

Sakinah Mawaddah and Rahmah is a sign of the power of Allah and the pleasure of Allah. from the word Taskunu from the word Sakana which is silent, calm before it was shaken and busy. From here, the house is named sakan because it is a place of inner peace. Every sex male or female, male or female is equipped with Allah with genitals that cannot function properly if they are not functioning. The perfection of the existence of beings such as humans is only achieved by the joining of each partner with a partner, especially if emphasized by the existence of the type of creature.

God creates sexual existence and therefore each type feels the need to find the opposite sex. Humans will feel restless, their minds are confused, and their souls will continue to flare up if there is no merging and the fulfillment of needs is not met. The command of marriage has been God Almighty that the chaos of the mind and the turmoil of the soul subside and each obtains peace. The word ilaiha explains about li taskunû which means or tends to go to Him so that the dating of the above verse means Allah.

The word mawadah is taken from the root of the word consisting of the letters (و) waw and (د) dl double (tasydid), which contain the meaning of love and hope. Ibn Faris in his work Maqayis. Al-Baqa'i believes that the series of letters implies spaciousness and emptiness. Mawaddah is the spaciousness and emptiness of the soul from the bad will. Thus this word means love, but love plus love.

Al-Baqa'i said that love which seems to bear fruit in attitude and treatment is similar to obedience as a result of admiration for someone. The meaning of the word mawaddah is almost the same as the word mercy, only that mercy is directed to the blessed in a state of need. The word mercy is aimed at weakness while mawaddah is not so. The word mawaddah must be proven in behavior while mercy does not have to be proven in behavior, but the hope is that the behavior implements attitude and behavior.

Building a sakinah family is the dream of every nation, including Indonesia. According to Zaitunah Subhan being a sakinah family, there are two aspects: first, fostering religious aspects to be very important as a supporter of the realization of the sakinah ma waddah family. Parents as leaders who are responsible for organizing diversity in the family of Rasulullah peace be upon him. Rasulullah peace be upon him said: "All of you are shepherds and will be held accountable for their shepherd ..., Allah has emphasized the obligation to guard the family against hellfire". 


\section{Conclusion}

Being a happy family is a command of the Qur'an. If you are unable to make each other happy then it is advisable not to get married.

\section{References}

[1] Harun Nasution, Islam ditinjau dari berbagai aspeknya jilid 2, UIP, UI Press, 2018.

[2] Kurnia Muhajarah, 'PERSELINGKUHAN SUAMI TERHADAP ISTRI DAN UPAYA PENANGANANNYA', Sawwa: Jurnal Studi Gender, 2017 $<$ https://doi.org/10.21580/sa.v12i1.1466>.

[3] Syamsul Ma'arif, 'Konsep Al- Qur'an Tentang Keluarga Bahagia', Gelar Sarjana Pendidikan Islam (S.Pdi), 2010.

[4] Ida Untari, Kanissa Puspa Dhini Putri, and Muhammad Hafiduddin, 'Dampak Perceraian Orang Tua Terhadap Kesehatan Psikologis Remaja', Profesi (Profesional Islam): Media Publikasi Penelitian, $2018<$ https://doi.org/10.26576/profesi.272>.Muhajarah.

[5] Husin Anang Kabalmay, 'Kebutuhan Ekonomi Dan Kaitannya Dengan Perceraian (Studi Atas Cerai Gugat Di Pengadilan Agama Ambon)', Tahkim, 2015.

[6] Anggit Sari and Nailul Fauziah, 'HUBUNGAN ANTARA EMPATI DENGAN KEPUASAN PERNIKAHAN PADA SUAMI YANG MEMILIKI ISTRI BEKERJA', Empati: Jurnal Karya Ilmiah S1 Undip, 2016.

[7] MILDA ITARES, 'FENOMENA PERNIKAHAN DI USIA MUDA DI KECAMATAN PONTIANAK BARAT KOTA PONTIANAK', Jurnal S-1 Sosiologi Untan, 2015.

[8] Arnoldus Donny, 'KEKERASAN DALAM RUMAH TANGGA TERHADAP ISTRI ( Studi Pada Lima Permasalahan Ekonomi Dalam Keluarga Di Kota Samarinda Kalimatan Timur )', Jurnal Sosiatri, 2016.

[9] A Syahraeni, 'KONSELING PERKAWINAN / KELUARGA ISLAMI', Al-Irsyad Al-Nafs, 2014.

[10] Maryatul Kibtyah, 'PERAN KONSELING KELUARGA DALAM MENGHADAPI GENDER DENGAN SEGALA PERMASALAHANNYA', Sawwa: Jurnal Studi Gender, 2014 $<$ https://doi.org/10.21580/sa.v9i2.641>.

[11] F. Litiloly and N. Swastiningsih, 'MANAJEMEN STRES PADA ISTRI YANG MENGALAMI LONG DISTANCE MARRIAGE’, EMPATHY Jurnal Fakultas Psikologi, 2014.

[12] Kusmana, Tantan Hermansyah UIN Syarif Hidayatullah Jakarta, Discourse of ideal Muslim family in Southest Asia: Reification and adaption, Journal of critical review,ISSN-2394-5125,Vol. 2 Issue 1, 2020. Pada tulisan ini menemukan konsep bahwa konsep keluarga ideal pada muslim tidak pernah berubah sejak hal tersebut ditetapkan dipertengahan abad.

[13] Yohannes Dion, 'Asuhan Keperawatan Keluarga Konsep Dan Praktik', in Asuhan Keperawatan Keluarga Konsep Dan Praktik, 2013.

[14] Dyah Satya Yoga, Ni Wayan Suarmini, and Suto Prabowo, 'Peran Keluarga Sangat Penting Dalam Pendidikan Mental, Karakter Anak Serta Budi Pekerti Anak', Jurnal Sosial Humaniora, 2015 $<$ https://doi.org/10.12962/j24433527.v8i1.1241>.

[15] Marmiati Mawardi, 'KELUARGA SAKINAH: KONSEP \& POLA PEMBINAAN', International Journal Ihya' 'Ulum Al-Din, $2017<$ https://doi.org/10.21580/ihya.17.2.1739>.

[16] Erniati, 'Keluarga Sakinah Dalam Perspektif Hadis Mawdhu'i', MUSAWA, 2017.

[17] Sri Jumini, "God Particles in the Perspective of the AlQuran Surah Yunus: 61 and Modern Science," in Journal of Physics: Conference Series, (2017). Vol. 795 : 012014. http:/ /stacks.iop.org/1742-6596/795/i=1/a=012014?key=crossref.0ea 736595d714b8b0bd244ad9 ae8d3a8. Diakses tanggal 07 Januari 2020.

[18] Noe, Raymood A, Hollenbeck, John. R, Gerhart, Barry, Wright, Patrick, M., "Human Resource Management, Gaining A Competitite Advantage", (New York: Mc Graw Hill International Edition, 2006), h. 4, Mokhtar, Noorzalya, et, al., "Factors affecting job satisfation of nurses at a private healthcare center in Malaysia. "Proceeding of the regional Al-Qura'an surat Ar-Rum [30]: 21. 
[19] Quraisy Shihab, Tafsir al-Misbah Pesan, Kesan, dan Keserasian al-Qur'an, Quraisy Shihab, Vol. 11, Lentera Hati, Jakarta: h. 34.

[20] Zaitunah Subhan, Menggagas Fiqh pemberdayaan perempuan, El-Kahfi, Jakarta 2008, h. 263.

[21] Baca di Jurnal Sosial Humaniora, Satya Yoga, Dyah Suarmini, Ni Wayan Prabowo, Suto, Peran Keluarga Sangat Penting dalam Pendidikan Mental, Karakter Anak serta Budi Pekerti Anak Keluarga memiliki peranan penting dalam membentuk karakter seorang anak. Dalam dalam tulisan ditemukan bahwa sebagai suatu sistem sosial terkecil, keluarga menanamkan nilai-nilai moral dalam kepribadian seorang anak. Pada masa pertumbuhan, seorang anak memiliki banyak pertanyaan mengenai hal-hal yang dirasanya baru, 2015.

[22] Quraisy Shihab, Tafsir al-Misbah Pesan, Kesan, dan Keserasian al-Qur'an, Quraisy Shihab, Vol 11, Lentera Hati, Jakarta: h. 447.

[23] Jurnal Happiness: The three traditional theory, Martin E.P Seligman dan Ed Royzman, July 2013.

[24] Muslimin Muslimin, "Hakekat Jiwa Dan Karakteristiknya Perspektif Al-Qur'an," Jurnal Pemikiran Keislaman 28, no. 1 (December 16, 2017): 94-122, https://ejournal.iai-trib akti.ac.id/index.php/tribakti/article/view/416. Diakses Tanggal 26 Januari 2020.

[25] Abdul Khaliq, Konsep keluraga sakinah dalam perspektif al-Qur'an oleh Abdul Khaliq yang ditulis didalam Jurnal Pengkajian penelitian ekonomi dan hukum Islam Pascasarjana IAIN Syeksh Nurjati Cirebon.

[26] Eka Prasetiawati, 'Penafsiran Ayat-Ayat Keluarga Sakinah, Mawaddah, Wa Rahmah Dalam Tafsir Al-Misbah Dan Ibnu Katsir', Nizham Journal of Islamic Studies, 2017.

[27] Abdul Kholik, 'KONSEP KELUARGA SAKINAH DALAM PERSPEKTIF QURAISH SHIHAB', INKLUSIF (JURNAL PENGKAJIAN PENELITIAN EKONOMI DAN HUKUM ISLAM), 2017 $<$ https://doi.org/10.24235/inklusif.v2i2.1912>. Prasetiawati.

[28] Lihat Skripsi, Yulianti Ratnasari dengan judul penelitian Konsep Keluarga Sakinah Menurut alGhazali Jurusan Tasawuf dan Psikoterapi Fakultas Ushuluddin dan Humaniora UIN Sunan Kalijaga Yogyakarta tahun 2018.

[29] E-Journal.metrouniv.ac.id, Eka Prasetiawati, Penafsiran ayat-ayat keluarga sakinah, ma waddah dan rahmah dalam tafsir al-Misbah dan tafsir Ibn Kathīr, IAIN Metro Ma'arif NU Metro, Praetiawati42@gmail.com.

[30] E-Journal IAIN Samarinda T-ISSN 1829-9067;E-ISSN 2460-6588, Mazahib Jurnal, Pemikiran Hukum Islam, Ismatullah, Konsep Sakinah Ma Waddah dan Rahmah dalm al-Qur'an (perspektif penafsiran al-Qur'an dan tafsirnya). Journal.iainsamarinda.ac.id, index.

[31] Yulianti Ratnasari, Konsep keluarga sakinah menurut al-Ghazali UIN Walisongo, 2018.

[32] Siti Wahyuni, Kebahagian rumah tangga sakinah (Studi atas terjemah Kitab Quratul 'uyun dan Kitab 'Uqdatul Lijain, Digital Repository, IAIN Purwokerto, 2019.

[33] Fathonaddin, Perkawinan sakinah ma waddah dan Rahmah, Skripsi UIN Alauddin Makasar, 2019 